\title{
Histomorphological effect of ascorbic acid on mercury chloride- induced changes on the cerebellum of adult wistar rats
}

\author{
IBEGBU, A. O. * , ANIMOKU ABDULRAZAQ, A., AYUBA MICHEAL, \\ BROSU DANIEL, ADAMU SADEEQ, A., AKPULU PETER, HAMMAN W. O., \\ UMANA U. E. and MUSA, S. A.
}

\begin{abstract}
Department of Human Anatomy, Faculty of Medicine, Ahmadu Bello University Zaria Kaduna State-Nigeria. 81006 *E-mail: aoibegbu@yahoo.com
\end{abstract}

\begin{abstract}
Introduction. Mercury is one of the most hazardous environmental contaminants to living organisms and the central nervous system has been shown to be the main target. Objective. The present work was aimed at evaluating the effect of ascorbic acid on mercury chloride-induced changes on the cerebellar cortex of adult Wistar rats. Material and method. Thirty Wistar rats of average weight of $200 \mathrm{~g}$ and were randomly divided into 6 groups of 5 rats each. The animals in Group 1 (control) were administered with distilled water, Groups 2 and 3 were administered with $52 \mathrm{mg} / \mathrm{kg}$ and $26.25 \mathrm{mg} / \mathrm{kg}$ body weight of $\mathrm{HgCl}$ respectively while Groups 4 and 5 were administered with $52 \mathrm{mg} / \mathrm{kg}$ of $\mathrm{HgCl}$ and $5 \mathrm{mg} / \mathrm{kg}$ of ascorbic acid and $26.25 \mathrm{gm} / \mathrm{kg}$ of $\mathrm{HgCl}$ and $5 \mathrm{mg} / \mathrm{kg}$ of ascorbic acid respectively, while Group 6 was administered with $5 \mathrm{mg} / \mathrm{kg}$ of ascorbic acid. The administration was through oral route, daily for 3 weeks. Results. The result of the biochemical parameters showed a significant increase $(\mathrm{P}<0.05)$ on the mean SOD and LPO values after the administration of mercury chloride and Ascorbic acid. Histological observation of the cerebellar cortex, showed normal histomorphology in Groups 1 and 6 while, the cerebellum in Groups 2, 3, 4 and 5 showed some degenerative, necrotic and cellular changes. Conclusion. However, ascorbic acid administration has shown to ameliorate the induced degenerative changes in the cerebellum caused by mercury chloride toxicity in Wistar rats.
\end{abstract}

Keywords: mercury chloride, cerebellar cortex, ascorbic acid, wistar rats.

\section{Introduction}

Mercury occur in the environment as a result of natural processes such as degassing from earth crust, emissions from volcanoes, evaporation from water bodies and anthropogenic processes from coal-fires, power stations, residential heating systems and waste incinerators (COX, 1997; BURGER and GOCHFELD, 2011). Mercury can also occur as a result of mining of mercury, gold, Copper, Zinc, Lead and Silver (AGENCY..., 1999). There is a growing appreciation of the effects that exposure to heavy metals may cause in the body and in particular, the brain and the nervous system. This is because some of these metals can cross the blood brain barrier and accumulate in the brain and cause damages (LANGFORD and FERNER, 1999; VALKO, MORRIS and CRONIN, 2005).

Animals and humans interact with their environment on a daily basis and as such are exposed to a broad spectrum of chemicals and heavy metals present in the environment through food, air and water (BURGER, JEITNER and GOCHFELD, 2011). The ancient Greek used mercury in ointments while the ancient Egyptians and Romans used it in cosmetics but in China, mercury was thought to prolong life, heal fractures and maintain general good health (CLARKSON, 1989; BRIAN and FRED, 1995). There are so many reported cases of mercury food poisoning in Sweden, Mexico, USA and the Minamata Bay incidence that led to the poisoning of over 800 people. Toxicity of mercury can result from vapor inhalation, ingestion or absorption through the skin. Nervous, digestive and renal systems are most commonly affected in mercury exposure while children and pregnant women are most vulnerable to mercury exposure (DE BONT, LAUWERYS, GOVAERTS et al., 1986; EUROPEAN..., 2005).

Fishes and mostly Tilapia, from Lagos Lagoon of Nigeria. are characterized with relatively high level of mercury concentration and this can be attributed to industrial effluents into the Lagoon (FODEKE, 1979). The level of mercury in fishes from Niger Delta area of Nigeria are less than $10 \mathrm{mg} / \mathrm{kg}$ (KAKULU and OSIBANJO, 1986). In Nigeria, not much work has been done to investigate the relative bio-accumulation potential of mercury on local aquatic species (OYEWO, 1998).

Some of the symptoms of mercury poisoning are Irritability, excitability, restlessness, irrational outburst of temper, depression, headache and dizziness amongst others (GRANT and LIPMAN, 2009). Other symptoms of mercury poisoning include itching, burning, pain, pink cheeks, swelling of fingertips and toes and shedding of the skin. A person suffering from mercury poisoning may experience profuse sweating, tachycardia, increased salivation, and hypertension (LUCKY, 1987; LANGFORD and FERNER, 1999). Affected children may show red cheeks, nose and lips, loss of hair, teeth, and nails, transient rashes, muscle weakness, kidney dysfunction, memory impairment and 
insomnia (HOROWITZ, GREENBERG, LING et al., 2002; LIUJI, XIANQIANG and HONGLI, 2002).

Ascorbic acids are natural antioxidants that prevent the production of free radicals induced by oxidative damage to lipids and lipoproteins in various compartments of cells and tissues (PADAYATTY, KATZ, WANG et al., 2003; WORLD..., 2003). Anti-oxides have been shown to react with superoxide (NISHIKIMI, 1975; WORLD..., 2004), hydroxyl radicals (MCGREGOR and BIESALSKI, 2006) and singlet oxygen (MOREIRA, SAYRE, ZHU et al., 2010).

Ascorbic acids are anti-oxidative substances that may protect the cells against the effects of free radicals which are molecules produced when the body break down foods or by exposure to tobacco smoke and radiation (CHIHUAILAF, CONTRERAS and WITTWER, 2002). These anti-oxides are regarded as a first-line protective agents that nullifies free radicals by donating a single electron to yield dehydroascorbic acid (VALKO, MORRIS and CRONIN, 2005; GEMMA, BACHSTETTER and BICKFORD, 2010). The aim of the present study was to evaluate the effect of ascorbic acid on mercury chloride-induced changes on the cerebellar cortex of adult Wistar rats.

\section{Materials and Methods}

\subsection{Experimental animals}

Thirty adult Wistar rats of average weight of $200 \mathrm{~g}$ were used for this study and were acclimatized for three weeks and kept in the Animal house of the Department. After acclimatization, the rats were divided into six groups of five rats per Group for the experiment.

\subsection{Experimental chemicals}

Twenty grams of Mercury chloride manufactured by May and Bakers Chemical Laboratory Limited Dagenham England while Vitamin C tablets manufactured by Jopan Pharmaceuticals Ltd. were purchased and used for the experiment.

\subsection{Animal experimentation}

Twenty Wistar rats were divided into 6 Groups of 5 animals each. Group 1 (Control) was administered with distilled water, Group 2 was given $52.5 \mathrm{mg} / \mathrm{kg}$ body weight of mercury chloride $(\mathrm{Hg})$, Group 3 animals were administered with $26.25 \mathrm{mg} / \mathrm{kg}$ body weight of $\mathrm{Hg}$, corresponding to $25 \%$ and $12.5 \%$ of $\mathrm{LD}_{50}$ of $\mathrm{Hg}$ respectively (LUCKY, 1987). Animals in Group 4 were given $52.5 \mathrm{mg} / \mathrm{kg}$ body weight of $\mathrm{Hg}$ and $5 \mathrm{mg} / \mathrm{kg}$ body weight of ascorbic acid, while Group 5 animals were administered with $26.25 \mathrm{mg} / \mathrm{kg}$ body weight of $\mathrm{Hg}$ and $5 \mathrm{mg} / \mathrm{kg}$ body weight of ascorbic acid and Group 6 rats were administered with $5 \mathrm{mg} / \mathrm{kg}$ body weight of ascorbic acid only corresponding to $10 \%$ of $\mathrm{LD}_{50}$ of ascorbic acid (FOOD..., 2007). The administration was by oral route daily and lasted for 3 weeks while animal feed and drinking water was allowed ad bilitum.

\subsection{Animals sacrifice}

After the administration, the animals were weighed and anaesthetized by inhalation of chloroform in the sacrificing chamber. Incision was made through the skin and muscle of the skull. The skull was opened through a mid sagittal incision and the cerebellum was removed and fixed in Bouin's fluid. The tissues were routinely processed and stained using haematoxylin and eosin and crystal violet methods.

\subsection{Estimation of oxidative parameters}

\subsubsection{Determination of Catalase activity}

Catalase activity was determined using the method described by Sinha (1972) and the absorbance was read at $570 \mathrm{~nm}$. Standard cure was made by plotting the absorbance obtained at various levels of the assay. The Catalase activity was obtained from the graph of the standard curve.

\subsubsection{Determination of superoxide dismutase (SOD) activity}

Superoxide Dismutase (SOD) activity was determined by a method described by Fridovich (1989). Absorbance was measured every 30 seconds up for a total of 150 seconds at $480 \mathrm{~nm}$ from where the SOD activity was calculated.

\subsubsection{Assessment of lipid peroxidation}

Lipid peroxidation as evidenced by the formation of TBARS was measured by the method of Niehaus and Samuelson (1968). The absorbance of the pink supernatant was measured against a reference blank using a spectrophotometer at $535 \mathrm{~nm}$.

\subsubsection{Assay of reduced Glutathione concentration}

Reduced glutathione (GSH) concentration measurements were done according to the method of Ellman (1959) as described by Rajagopalan, Jallepalli, Rago et al. (2004), and the absorbance was read at $412 \mathrm{~nm}$.

\subsubsection{Statistical analysis}

All data were presented as mean \pm SD. For establishing significant differences, data were analyzed by one-way analysis of variance (ANOVA), followed by Tukey post hoc test. Values were considered statistically significant if $\mathrm{P}$ value is less than or equal to 0.05 ( $\mathrm{p} \leq 0.05)$.

\section{Results}

\subsection{Physical observation of the animals}

The result of physical observation of the animals showed that rats in Group 1 were very active while Group 2 animals showed less activity, gnawing and restlessness with watery feces. The animals in Group 3 showed gnawing and restlessness characterized by watery feces, while Group 4 animals exhibited restlessness. The result of physical observation showed little gnawing in Group 5 animals with more activity when compared to Group 2 and Group 4 while Group 6 animals showed no changes in their physical activity as in Group one.

\subsection{Oxidative parameters}

The result of the analysis of oxidative stress markers namely Catalase, SOD, glutathione reductase and lipid peroxidation following administration of mercury chloride and ascorbic acid showed increase and decrease in some parameters as shown in Table 1 . The result showed a significant decrease $(\mathrm{P}<0.05)$ in Catalase, SOD and Glutathione reductase in Groups 2, 3 and 4 when compared with the Control, and a 
significant increase $(\mathrm{P}<0.05)$ in Lipid peroxidase in Groups 2 and 3 , and a significant decrease $(\mathrm{P}<0.05)$ in Groups 5 and 6 when compared with the Control as shown in Table 1.

\subsection{Histological observations}

The results of histological observation of the cerebellar cortex of animals in Group 1, showed normal histomorphology of the cerebellar cortical cells and layers as shown in Figure 1 while the results of histological observation of the cerebellum of animals in Group 2 showed degeneration and necrosis of the Purkinje cells of the Purkinje cell layer of the cerebellar cortex as shown in Figure 2.

The results of the observations in the cerebellum of animals in Group 3 showed separation of the Purkinje cells due to the degeneration of Purkinje cells, degenerated Stallate cells in the cerebellum as shown in Figure 3 while the results of the observation of the cerebellar cortices of animals in Group 4 showed few degeneration of Purkinje

Table 1. Effect of ascorbic acid on mercury chloride-induced changes on the oxidative markers in experimental animals.

\begin{tabular}{|c|c|c|c|c|c|}
\hline $\mathrm{S} / \mathrm{N}$ & Groups & $\begin{array}{l}\text { CATmm } / \mathrm{ml} \\
\text { Mean } \pm \text { SD }\end{array}$ & $\begin{array}{c}\text { SOD }(\text { mUnits } / \mathrm{L}) \\
\text { Mean } \pm \text { SD }\end{array}$ & $\begin{array}{c}\text { GLU }(\mathrm{mm} / \mathrm{ml}) \\
\text { Mean } \pm S D\end{array}$ & $\begin{array}{c}\text { LPO }(\mu \mathrm{M} / \mathrm{L}) \\
\text { Mean } \pm \text { SD }\end{array}$ \\
\hline \multirow[t]{2}{*}{1} & I & & & & \\
\hline & (control) & $23.25 \pm 1.19$ & $604.65 \pm 60.32$ & $14.29 \pm 1.19$ & $57.46 \pm 3.35$ \\
\hline \multirow[t]{2}{*}{2} & II & & & & \\
\hline & $52.5 \mathrm{mgHg} \mathrm{Cl}$ & $12.52 \pm 5.30 *$ & $358.15 \pm 12.94 *$ & $10.04 \pm 1.16^{*}$ & $91.55 \pm 6.24^{*}$ \\
\hline \multirow[t]{2}{*}{3} & III & & & & \\
\hline & $26.25 \mathrm{mg} \mathrm{HgCl}$ & $13.52 \pm 5.62 *$ & $382.75 \pm 24.39^{*}$ & $11.54 \pm 3.03^{*}$ & $70.39 \pm 6.59^{*}$ \\
\hline \multirow[t]{2}{*}{4} & IV & & & & \\
\hline & $52.5 \mathrm{mg} / \mathrm{kg} \mathrm{HgCl}+$ Vit. C & $18.18 \pm 1.28^{*}$ & $472.75 \pm 77.15^{*}$ & $12.50 \pm 2.26^{*}$ & $52.82 \pm 14.79$ \\
\hline \multirow[t]{2}{*}{5} & $\mathrm{~V}$ & & & & \\
\hline & $26.25 \mathrm{mg} / \mathrm{kg} \mathrm{HgCl}+$ Vit. C & $20.29 \pm 3.57$ & $526.50 \pm 50.21$ & $13.57 \pm 0.81$ & $47.75 \pm 3.25$ * \\
\hline \multirow[t]{2}{*}{6} & VI & & & & \\
\hline & Vit.C5mg/ kg & $20.61 \pm 3.32$ & $580.25 \pm 35.71$ & $14.05 \pm 1.35$ & $41.86 \pm 5.78^{*}$ \\
\hline
\end{tabular}

${ }^{*} \mathrm{P}<0.05, \mathrm{CAT}=$ Catalase; $\mathrm{SOD}=$ Superoxide Dismutase; GLU=Glutathione Reductase; LPO=Lipid-peroxidation.

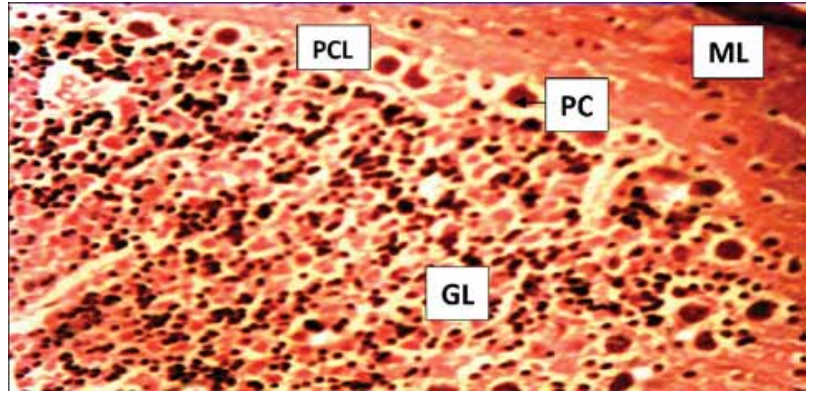

Figure 1. A transverse section of cerebellar cortex of the Control Group, showing normal Molecular layer (ML), Purkinje cell layer (PCL), Purkinje cells (PC) and Granular layer (GL). H \& $\mathrm{E}, \mathrm{Mg}$ X 250 .

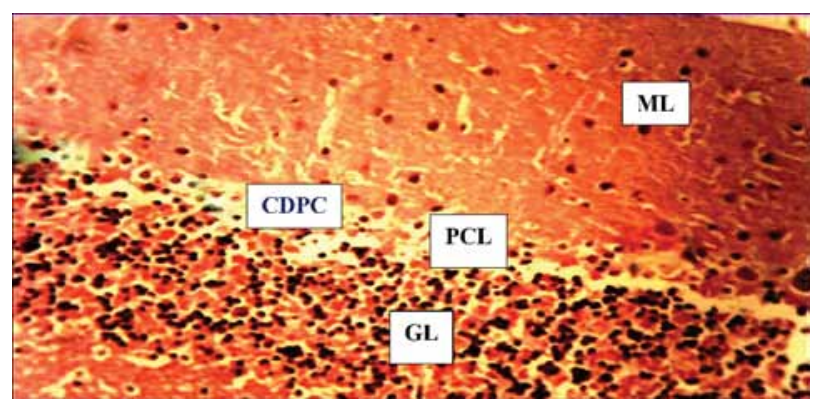

Figure 2. A transverse section of cerebellar cortex of animals in Group 2, showing the Molecular layer (ML), Purkinje cell layer (PCL), Complete degeneration of Purkinje cells (CDPC) with no Purkinje cell and Granular layer (GL). H \& E, Mg X 250.

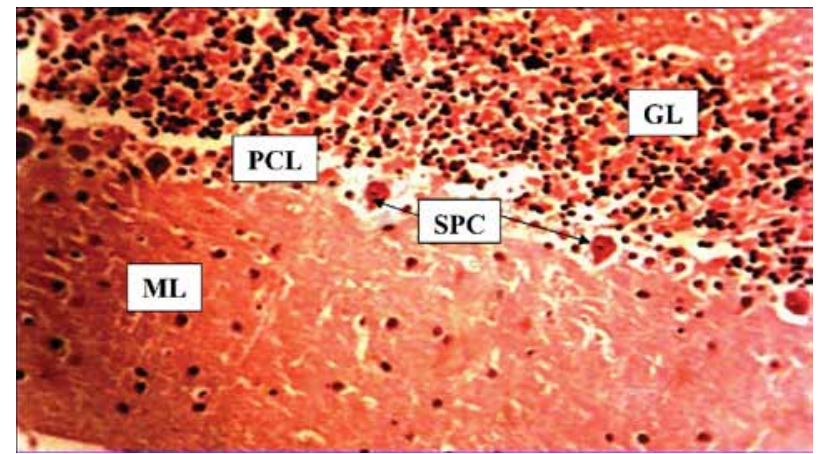

Figure 3. A transverse section of the cerebellar cortex of animals in Group 3, showing the Molecular layer (ML), Few and separated Purkinje cells (SPC) and Granular layer (GL). H \& E, Mg X 250.

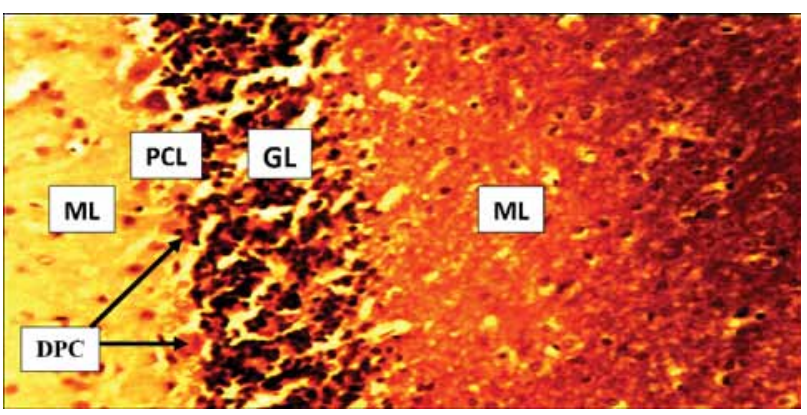

Figure 4. A transverse section of cerebellar cortex of animals in Group 4, showing the Molecular layer (ML), Degenerated Purkinje cells (DPC) and Granular layer (GL). H \& E, $\operatorname{Mg}$ X 250. 


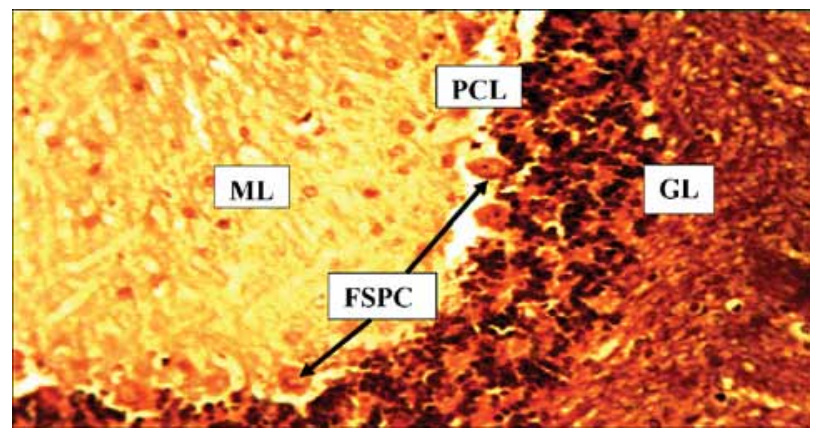

Figure 5. A transverse section of the cerebellar cortex of the animals in Group 5, showing the Molecular layer (ML), Purkinje Cell Layer (PCL) with Few and Separated Purkinje cells (FSPC) and Granular layer (GL). H \& E, Mg X 250.

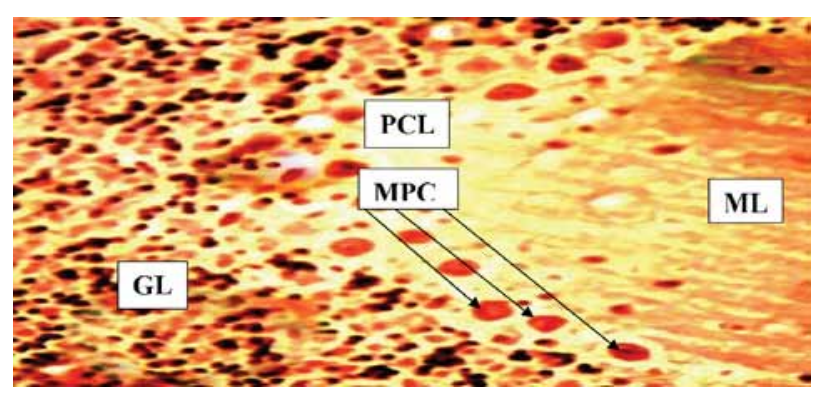

Figure 6. A transverse section of the cerebellar cortex of animals in Group 6, showing the Molecular layer (ML), Purkinje Cell Layer (PCL), with Many Purkinje cells (MPC) and normal Granular layer (GL). H \& E, Mg X 250.

cells of the cerebellum with clumping and congestion of cells as shown in Figure 4.

The results of the observation of the cerebellar cortices of animals in Group 5 showed displacement of Purkinje cell nuclei, separation of Purkinje cells due to the degeneration of Purkinje cells and the granular and molecular layers of the cerebellum were not affected as shown in Figure 5, while the results of the observation of the cerebellar cortices of animals in Group 6 showed normal arrangement of the layers and cells of the cerebellum as shown in Figure 6.

\section{Discussion}

The present study showed degeneration and necrosis of Purkinje cells in the Purkinje cell layers of the cerebellum of the adult Wistar rats induced with different concentration of mercury chloride, while all the layers and cells of the cerebellum of the Control group showed no histological changes. The findings from the present study agree with the findings which reported that many heavy metals such as mercury, lead, cadmium and other organic compounds have the capacity to damage the nervous system (MAURICE and JAMES, 1972; VERINA, ROHDE and GIULARTE, 2007). This changes may be transient but permanent abnormalities may be induced only by sustained exposure of these chemicals in an excessive quantity (WOLF, RAPOPORT and SCHWEIZER, 2009). Recent studies have shown that the most sensitive elements of the cerebellar cortex to these chemicals are the Purkinje cells, which react to these noxious substances by undergoing degeneration and as such disappear from their relative positions in the Purkinje cell layer (JOMOVA and VOLKO, 2011; FARINA, AVILA, ROCHA et al., 2013).

It has been shown that cerebellar dysfunction may occur in association with exposure to a wide variety of toxins including heavy metals such as mercury, lead, thallium, manganese, drugs and solvents (WOODSIDE, MCCALL, MCGARTLAND et al., 2005; BURGER, JEITNER, DONIO et al., 2013). These toxins may adversely affect the cerebellum directly or as part of a more generalized brain effects (JOMOVA, VONDRAKOVA, LAWSON et al., 2010). Findings from other studies, show that the cerebellar neurodegeneration will lead to lesions of the cerebellum giving rise to signs and symptoms generally called cerebellar syndromes which include muscular hypotonia, intentional tremor, nystagmus, scanning speech and ataxic gait (FINE, IONITA and LOHR, 2002; GEMMA, VILA, BACHSTETTER et al., 2007; WOLF, RAPOPORT and SCHWEIZER, 2009).

The present study has shown that ascorbic acid has an ameliorative effect on the cerebellum of the experimental animals induced toxicity of the mercury chloride. Administration of ascorbic acid has shown some improvements in the prevention of degeneration of brain cells when compare with rats exposed to only mercury chloride. From the present observation, it has been shown that there is a direct relationship between the Concentration of mercury chloride, ascorbic acids and the level of neurological damage in the cerebellum. The present study showed that the ascorbic acid administration reduced the damage done to the cerebellum was in agreement with the findings that showed that natural agents rich in antioxidants are involved in the improvement in enzymatic activity and hence in the reduction of oxidative stress (AHAMED and SIDDIQUI, 2007; FARINA, AVILA, ROCHA et al., 2013). This may play a significant role in the reversion of mercury toxicity by forming inert complexes and inhibiting their toxicity on the dopaminergic neurons (FLORA, SAXENA and MEHTA, 2007; JOMOVA and VOLKO, 2011).

The present study showed a significant increase in the mean SOD levels in the experimental groups and a significant decrease in the LPO mean values when compared to the Control. The increase and decrease in the mean values of SOD and LPO could be related to the ameliorative effects of the antioxidative activities of Ascorbic acid on mercury induced toxicity in the experimental animals. It has been shown that heavy metals such as mercury, lead and thallium have been reported to reduce anti-oxidative enzymes such as SOD, CAT, GLU and Lipid peroxidase (LPO) (WOODSIDE, MCCALL, MCGARTLAND et al., 2005; FARINA, AVILA, ROCHA et al., 2013).

This present study agreed with the findings that showed that oxidative stress was an important component of the mechanism of toxicity by heavy metals (GUTIERREZ, MAZZOTTI, ARAUJO et al., 2006). It has been shown that acute exposure to mercury increases LPO and decreases SOD levels in experimental animals. The decrease in the activity of antioxidative enzymes such as superoxide dismutase level and the elevation of Lipid peroxidation, suggest the formation of free radicals and the participation of free radical induced oxidative cell injury in mediating the toxic effect 
of mercury (JOMOVA, VONDRAKOVA, LAWSON et al., 2010). There is reduction in the antioxidant defense system by SOD in mercury toxicity leading to the disruption of pro-antioxidant balance in the body. The increase in Lipid peroxidation might be due to peroxidation of unsaturated fatty acids within the cells in the body. Thus, increased Lipid peroxidation is suggestive of progressive increase in cellular deformity, increase in membrane permeability and rigidity, and disruption of structural and functional integrity of cell organelles (GEMMA, VILA, BACHSTETTER et al., 2007).

\section{Conclusion}

Mercury exposure induced a significant degeneration in the cerebellar features of the adult Wistar rats. Moreover, ascorbic acid has shown to protect significantly the neurotoxicity induced by mercury chloride administration. As such, people exposed to mercury poison should limit exposure time or wear protective coverings. Consumers of mercury containing cosmetics, should always be conscious of the percentage of mercury in the products and should consume food rich in ascorbic acid and other antioxidants since it has been shown that antioxidants help in the reduction of the damage induced by mercury chloride.

\section{References}

AGENCY FOR TOXIC SUBSTANCES AND DISEASE REGISTRY - ATSDR. Toxicological profile for mercury. Atlanta: US Department of Health and Human Services, 1999.

AHAMED, M. and SIDDIQUI, MK. Low level lead exposure and oxidative stress: current opinions. Clinica Chimica Acta, 2007, vol. 383, p. 57-64. PMid:17573057. http://dx.doi.org/10.1016/j. cca.2007.04.024

BRIAN, G. and FRED, S. Distribution and effect of mercury. Mercury Action News, 1995, vol. 3, n. 3, p. 11-18.

BURGER, J. and GOCHFELD, M. Mercury and selenium levels in 19 species of saltwater fish from New Jersey as a function of species, size, and season. Science of the Total Environment, vol. 409, n. 8, p. 1418-1429, 2011. PMid:21292311 PMCid:PMC4300121. http://dx.doi.org/10.1016/j.scitotenv.2010.12.034

BURGER, J., JEITNER, C., DONIO, M., PITTFIELD, T. and GOCHFELD, M. Mercury and selenium levels, and selenium: mercury molar ratios of brain, muscle and other tissues in bluefish (Pomatomus saltatrix) from New Jersey, USA. Science of the Total Environment, vol. 15, n. 443, p. 278-86, 2013. PMid:23202378 PMCid:PMC4321722. http://dx.doi.org/10.1016/j. scitotenv.2012.10.040

BURGER, J., JEITNER, C. and GOCHFELD, M. Locational differences in mercury and selenium levels in 19 species of saltwater fish from New Jersey. Journal of Toxicology and Environmental Health A, 2011, vol. 74, n. 13, p. 863-874. PMid:21598171 PMCid:PMC4300130. http://dx.doi.org/10.1080/15287394.2 011.570231

CHIHUAILAF, RH., CONTRERAS, PA. and WITTWER, FG. Pathogenesis of oxidative stress: Consequences and evaluation in animal health. Veterinaria México, 2002, vol. 33, n. 3, p. 265-283.

CLARKSON, TW. Mercury. Journal of the American College of Toxicology, 1989, vol., 84, n. 7, p. 1291-1296. http://dx.doi. org/10.3109/10915818909009120
COX, R. The pillar of celestial fire. 1st ed. World Publishing, 1997. p. 260.

DE BONT, B., LAUWERYS, R., GOVAERTS, H. and MOULIN, D. Yellow mercuric oxide ointment and mercury intoxication. European Journal of Pediatrics, 1986, vol. 145, p. 217-218. PMid:3769977. http://dx.doi.org/10.1007/BF00446069

ELLMAN, GL. Tissue sulfhydryl groups. Archives of Biochemistry and Biophysics, 1959, vol. 82, p. 70-72. http://dx.doi. org/10.1016/0003-9861(59)90090-6

EUROPEAN COMMISSION. 101 Communication from the Commission to the Council and the European Parliament on Community Strategy. Concerning Mercury Extended Impact Assessment. Brussels, 2005, p. 12.

FARINA, M., AVILA, DS., ROCHA, JB. and ASCHNER, M. Metals, oxidative stress and neurodegeneration: a focus on iron, manganese and mercury. Neurochemistry International, vol. 62, n. 5, p. 575-594, 2013. PMid:23266600 PMCid:PMC3615063. http://dx.doi.org/10.1016/j.neuint.2012.12.006

FINE, EJ., IONITA, CC. and LOHR, L. The history of the development of the cerebellar examination. Seminars Neurology, 2002, vol. 22 , n. 4 , p. 375-384. PMid:12539058. http://dx.doi. org/10.1055/s-2002-36759

FLORA, SJ., SAXENA, G. and MEHTA, A. Reversal of lead-induced neuronal apoptosis by chelation treatment in rats: Role of ROS and intracellular Ca+. Journal of Pharmacology and Experimental Therapentics, 2007, vol. 322, p. 108-173. PMid:17431133. http:// dx.doi.org/10.1124/jpet.107.121996

FODEKE, A. Studies on heavy metals and microbial contamination of Tilapia sp in Lagos Lagoon. Nigeria: University of Lagos, 1979. [M.Sc Thesis].

FOOD STANDARDS AGENCY. Vitamin C risk assessment. 2007. Available from: <http://www.food.gov.uk/multimedia/pdfs/ evm_c.pdf $>$. Access in: 22/05, 2012.

FRIDOVICH, I. Superoxide dismutase: an adaptation to a pragmatic gas. Journal of Biological Chemistry, 1989, vol. 264, p. 7761-7764. PMid:2542241

GEMMA, C., BACHSTETTER, AD. and BICKFORD, PC. Neuron-microglia dialogue and hippocampal neurogenesis in the aged brain. Aging and Disease, 2010, vol. 1, n. 3, p. 232-244. PMid:21961084 PMCid:PMC3180926

GEMMA, C., VILA, J., BACHSTETTER, A. and BICKFORD, PC. Oxidative stress and the aging brain: from theory to prevention. In RIDDLE, DR. (Ed.). Brain aging: models, methods, and mechanisms. Boca Raton: CRC Press, 2007. Chapter 15.

GRANT, LD. and LIPMAN, M. Environmental toxicant: human exposure and their effect. 3rd ed. 2009. p. 108-112

GUTIERREZ, LL.; MAZZOTTI, NG., ARAUJO, A., KLIPEL, R., FERNANDES, T., LLESUY, F. and BELLO-KLEIN, A. Peripheral markers of oxidative stress in chronic mercuric chloride intoxication. Journal of Medical and Biological Research, 2006, vol. 39, n. 6, p. 767-772. http://dx.doi.org/10.1590/S0100879X2006000600009

HOROWITZ, Y., GREENBERG, D., LING, G. and LIFSHITZ, M. Acrodynia: a case report of two. Archives of Disease in Childhood, 2002, vol. 86, n. 6, p. 453. PMid:12023189 PMCid:PMC1762992. http://dx.doi.org/10.1136/adc.86.6.453

JOMOVA, K. and VALKO, M. Advances in metal-induced oxidative stress and human disease. Toxicology, 2011, vol. 283, n. 2-3, p. 65-87. PMID: 21414382. http://dx.doi.org/10.1016/j. tox.2011.03.001 
JOMOVA, K., VONDRAKOVA, D., LAWSON, M. and VALKO, M. Metals, oxidative stress and neurodegenerative disorders. Molecular and Cellular Biochemistry, 2010, vol. 345, n. (1-2), p. 91-104.

KAKULU, SE. and OSIBANJO, O. A baseline study of mercury in fish and sediments in the Niger Delta Area of Nigeria. Environmental Pollution (series B), 1986, vol. 2, p. 315-322.

LANGFORD, $\mathrm{N}$ and FERNER, R. Toxicity of mercury. Journal of Human Hypertension, 1999, vol. 13, n. 10, p. 651-656. PMid:10516733. http://dx.doi.org/10.1038/sj.jhh.1000896

LIUJI, C., XIANQIANG, Y. and HONGLI, J. Tea catechins protect against lead induced cytotoxicity, lipid peroxidation, and membrane fluidity in HepG2 cells. Toxicological Sciences, 2002, vol. 69, p. 145-156.

LUCKY, TD. Metal toxicity in mammals. New York: Plenum Press, 1987. p. $20-28$

MAURICE, V. and JAMES, AF. The nutritional and metabolic diseases of the cerebellum. Clinical and pathological aspects. In WILLIAM, SF. and WILLIAM, DW. (Eds.). The cerebellum in health and diseases. London: Adam Hilger Ltd., 1972. p. 412-449.

MCGREGOR, GP. and BIESALSKI, HK. Rationale and impact of vitamin C in clinical nutrition. Current Opinion in Clinical Nutrition \& Metabolic Care, 2006, vol. 9, n. 6, p. 697-703. PMid:17053422. http://dx.doi.org/10.1097/01.mco.0000247478.79779.8f

MOREIRA, PI., SAYRE, LM., ZHU, X., NUNOMURA, A., SMITH, MA. and PERRY, G. Detection and localization of markers of oxidative stress by in situ methods: application in the study of Alzheimer disease. Methods in Molecular Biology, 2010, vol. 610, p. 419-434. PMid:20013193. http://dx.doi.org/10.1007/978-160327-029-8_25

NIEHAUS, WG. and SAMUELSON, B. Formation of malnaldehyde from phospholipid arachidonate during microsomal lipid peroxidation. European Journal of Biochemistry, 1968, vol. 6, p. 126-130. http://dx.doi.org/10.1111/j.1432-1033.1968. tb00428.x

NISHIKIMI, M. Oxidation of ascorbic acid with superoxide anion generated by the xanthine-xanthine oxidase system. Biochemistry and Biophysics Research Communication, 1975, vol. 63, p. 463-468. http://dx.doi.org/10.1016/0006-291X(75)90710-X

OYEWO, EO. Industrial sources and distribution of heavy metals in Lagos lagoon and their biological effects on estuarine animals. Nigeria: University of Lagos, 1998. 274 p. [PhD Thesis].
PADAYATTY, SJ., KATZ, A., WANG, Y., ECK, P., KWON, O. LEE, J., CHEN, S. and CORPE, C. Vitamin C as an antioxidant: evaluation of its role in disease prevention. Journal of the American College of Nutrition, 2003, vol. 22, n. 1, p. 18-35. PMid:12569111. http://dx.doi.org/10.1080/07315724.2003.10719272

RAJAGOPALAN, H., JALLEPALLI, PV., RAGO, C., VELCULESCU, VE., KINZLER, KW., VOGELSTEIN, B. and LENGAUER, C. Inactivation of hCDC4 can cause chromosomal instability. Nature, 2004, vol. 428, n. 6978, p. 77-81. PMid:14999283. http://dx.doi.org/10.1038/nature02313

SINHA, AK. Colorimetric assay of catalase. Analytical Biochemistry, 1972, vol. 47, p. 389-399. http://dx.doi.org/10.1016/00032697(72)90132-7

VALKO, M., MORRIS, H. and CRONIN, MT. Metals, toxicity and oxidative stress. Current Medicinal Chemistry, 2005, vol. 12, n. 10, p. 1161-1208. PMid:15892631. http://dx.doi. org/10.2174/0929867053764635

VERINA, T., ROHDE, CA. and GIULARTE, TR. Environmental lead exposure during early life alters granule cell neurogenesis and morphology in the hippocampus of young adult rats. Neuroscience, 2007, vol. 145, p. 1037-1047. PMid:17276012 PMCid:PMC1892316. neuroscience.2006.12.040 http://dx.doi.org/10.1016/j.

WOLF, U., RAPOPORT, MJ. and SCHWEIZER, TA. Evaluating the affective component of the cerebellar cognitive affective syndrome. Journal of Neuropsychiatry Clinical. Neurosciences, 2009, vol. 21, n. 3, p. 245-253. PMid:19776302. http://dx.doi. org/10.1176/jnp.2009.21.3.245

WOODSIDE, J., MCCALL, D., MCGARTLAND, C. and YOUNG, I. Micronutrients: dietary intake vitamin C supplement use. Proceedings of the Nutrition Society, 2005, vol. 64, n. 4, p. 543553. PMid:16313697. http://dx.doi.org/10.1079/PNS2005464

WORLD HEALTH ORGANIZATION - WHO. Elemental mercury and inorganic mercury compounds: human health aspects. Geneva, 2003. Concise International Chemical Assessment Document 50 .

WORLD HEALTH ORGANIZATION - WHO. Vitamin and mineral requirements in human nutrition, 2nd ed. Geneva, 2004.

Received November 31, 2013 Accepted December 22, 2014 